lack of confidence in the NHS organising itself to meet this challenge. The private sector will realise, however, that purchasers will have finite funds and care will be rationed. Providing these facilities on a large scale may therefore be a risky investment.

A new lead from the centre is needed. The existence of these patients needs urgent recognition followed by an acceptance that providing them with services remains the responsibility of local mental illness and mental handicap services. Some deprived inner city areas seem to have more than their fair share of such patients, ${ }^{21}{ }^{26}$ further supporting arguments against the current allocation of resources on a per caput basis. ${ }^{27}$ University departments of psychiatry, which have previously lent academic respectability to some of today's disastrous policies, should turn more of their attention to the casualties of community care and as different models of care evolve they should be properly evaluated. ${ }^{28-30}$ The biggest problem, as always, is money. Without adequate capital for providing the necessary facilities any new policy will ultimately flounder.

Senior Lecturer in Forensic Psychiatry,

JEREMY W COID

Department of Psychological Medicine,

St Bartholomew's Hospital,

London EC1A 7BE

Barton R. Institutional neurosis. Bristol: John Wright, 1959.

2 Goffman E. Asylums. Harmondsworth: Pelican, 1961.

3 Wing JK, Brown GW. Institutionalism and schizophrenia. Cambridge: Cambridge University Press, 1970.

4 Day K. Mental handicap and community care. Br f Hosp Med 1988:40:249.

5 Mann SA, Cree W. "New" long-stay psychiatric patients: a national sample survey of fifteen mental hospitals in England and Wales 1972/3. Psychol Med 1976;6:603-16.

6 MacCready RG, Wilson AOS, Burton L.L. The Scottish survev of "new chronic" inpatients. $\mathrm{Br}$. Psvchiatry 1983;143:564-71.
7 Thornicroft G, Bebbington P. Deinstitutionalisation - from hospital closure to service develop ment. Br f Psychiatry 1989;155:739-53.

8 Curson DA, Patel M, Liddle PF, Barnes TRE. Psychiatric morbidity of a long stay hospital population with chronic schizophrenia and implications for future community care. $B M \mathcal{J}$ 1988;297:819-22.

9 Carson J, Shaw L. Which patients first: a study from the closure of a large psychiatric hospital. Health Trends 1989;21:117-20.

10 Geller JL, Fisher WH, Wirth-Cauchon JL, Simon LJ. Second generation deinstitutionalisation. II. The impact of Brewster $v$ Dukakis on correlates of community and hospital utilisation. $\mathrm{Am} \mathcal{J}$ Psychiatry 1990;147:988-93.

11 Geller JL, Fisher WH, Simon LJ, Wirth-Cauchon JL. Second generation deinstitutionalisation. I. The impact of Brewster $v$ Dukakis on state hospital case mix. A m J Psychiatry 1990;147:982-7.

12 Hassall C, Rose S. Powick Hospital, 1978-86: a case register study. In: Wing JK, ed. Health services planning and research. Contributions from psychiatric case registers. Dorchester: Gaskell, 1989:5869.

13 Bachrach LL. Young adult chronic patients: an analytical review of the literature. Hosp Communty Psychiatry 1982;33:189-97.

14 Pepper B, Rygiewicz H, eds. The young adult chronic patient. San Francisco: Jossey-Bass, 1982. Sheets JL, Prevost JA, Reihman J. Young chronic patients: three hypothesised subgroups. Hosp Community Psychiatry 1982;33: 197-203.

16 Lamb HR. Structure: the neglected ingredients of community treatment. Arch Gen Psychiatry 1980;37:1224-8.

7 Dell S, Robertson G. Sentenced to hospital. Offenders in Broadmoor. Oxford: Oxford University Press, 1988. (Maudsley Monograph No 32. )

18 Coid JW. Mentally abnormal offenders on remand. I. Rejected or accepted by the NHS? II Comparison of services provided by Oxford and Wessex regions. BMJ 1988;296:1779-84.

19 Weller MPI, Weller BGA. Mental illness and social policy. Med Sci Law 1988:28:47-53.

20 Marshall $M$. Collected and neglected: are Oxford hostels for the homeless filling up with disabled psychiatric patients? BMF 1989;399:706-9.

psychiatric patients? B.MF 1989:399:706-9.
Coid JW. A survey of patients from five health districts receiving special care in the private sector. Bulletin of the Royal College of P'sychiatrists (in press).

22 Bleuler M. The schizophrenic disorders: longterm patient and family studies. New Haven: Yale University Press, 1978.
Under

23 Ciompi L, Muller C. Lebesweg und Aller der Schizophrenen. Berlin: Springer, 1976

24 Shepherd M, Watt D, Falloon I, Smeeton N. The natural history of schizophrenia: a five-year follow up study of outcome and prediction in a representative sample of schizophrenics. Psychol Med; Monogr Suppl 15, 1989.

25 Goldstein JM, Bassuk EL, Holland SK, Zimmer D. Identifying catastrophic psychiatric cases. Med Care 1988;26:790-9.

26 Inter-register Technical Committee. Psychiatric care in 8 register areas. Statistics from eight psvchiatric case registers in Great Britain 1976-1981. Southampton: University of Southampton, 1982.

27 Hirsch SR. Psychiatric beds and resources: factors influencing bed use and service planning. London: Roval College of Psychiatrists, 1988. (Gaskell Psychiatry: Series.)

28 Gibbons JC. Care of "new" long-stay patients in a district general hospital psychiatric unit. The first wo years of a hospital-hostel. Acta Psychiatr Scand 1986:73:582-8.

29 Pullen GP. The Oxford service for the young adult chronically mentally ill. Bulletin of the Royal College of Psychiatrists 1987:11:377-9.

30 Pullen GP. The Oxford service for the young adult chronically mentally ill. Bulletin of the Royal College of Psychiatrists 1987:12:64.

\title{
Health check ups for all?
}

\section{Given time, the results of fapanese screening might provide the answer}

Two radical changes are in train for the NHS. Firstly, health authorities will be responsible not simply for health care but for the health of their populations. And, secondly, under their new contract general practitioners have to practise preventive medicine. These changes pose interesting and fundamental questions that are linked. How much can health authorities influence health? And what contribution might preventive medicine make?

Since McKeown we have been wary of making extravagant claims for the benefits of health care. Although it may reduce disability, pain, and suffering - frequently used measures of medical outcome - McKeown argued that improvements in life expectancy have been secondary to improved nutrition and environmental conditions. ${ }^{2}$ Supporting his thesis are the socioeconomic differences in health in Britain ${ }^{3}$ and the improvement in life expectancy in countries such as Japan ${ }^{+}$: differences in health care are unlikely to explain them.

The time has therefore come for health authorities to consider how they might affect the determinants of healthone aspect of the "new" public health medicine. Complementing this public health activity is preventive medicine. There are grounds for optimism in primary care: evidence of efficacy of general practitioners' advice on cigarette smoking and alcohol consumption ${ }^{56}$ and on the treatment of hypertension.

Screening has come under critical scrutiny of both its costs and benefits. ${ }^{7}$ Studies in the elderly have focused more on functional and social assessments than on biochemical screening or medical examinations. A randomised trial in Copenhagen, using checks at three month intervals, suggested that such checks result in reductions in mortality and lengths of hospital stay. ${ }^{8}$ A study in south Wales showed an apparent reduction in mortality in one of two centres, ${ }^{9}$ and other studies have shown improvements in morale. ${ }^{10}$ By discovering unreported illness, however, screening may make things worse. Detecting disease early does not mean that we can alter its course or improve the quality of life.

The paper of Tatara et al (p 615) is relevant to these issues. ${ }^{11}$ In 1982 a new law was passed in Japan that provided periodical physical examinations, health education, and counselling for all Japanese residents aged 40 and over. Where the service was not provided by the place of work, local government provided it. In 1988 nearly a third of the population received health check ups under this scheme. To evaluate its effect Tatara et al surveyed all 509 Japanese cities with a population between 30000 and 200000 . They report an inverse relation between the uptake of health check ups in adults aged 40 and over and hospital use by those aged 70 and over.

Unlike the randomised trials, this was an "ecological" study, comparing groups rather than individuals. Attempting to avoid the problem of confounding (the groups might differ by more than their rates of health check up), the authors examined changes over the four years since the check ups 
started. The rate of health check ups was assessed in people aged 40 and over; the decreases in inpatient stay were assessed in the elderly. This raises the possibility that the rate of health check ups might be a marker for something else, perhaps the quality of health services, as Tatara et al suggest. Before suggesting that the relation that they found was causal, however, it would be necessary (at the very least) to have examined health check up rates in elderly people or to have followed up subjects for much longer.

Does this study have implications for European health services? If the relation is causal then the results are of potentially profound importance, suggesting that screening offered to middle aged people may reduce hospital costs incurred by elderly people. The results, however, are not relevant to the surveillance of patients aged 75 and over, which the new contract requires of general practitioners. They are obliged to check sensory functions (hearing and vision), mobility, mental condition, physical condition and continence, social environment, and use of medicines. The overlap between this and the Japanese programme is small. The paper by Tatara et al also raises the question of which components of their health checks are of value. Health professionals, obliged by governments to undertake check ups, reasonably expect that only those components with proved effectiveness will be included.

M G MARMOT

Professor of Community Medicine

A HAINES

Professor of Primary Health Care

University College and Middlesex School of Medicine,

University College London,

London WC1E 6EA

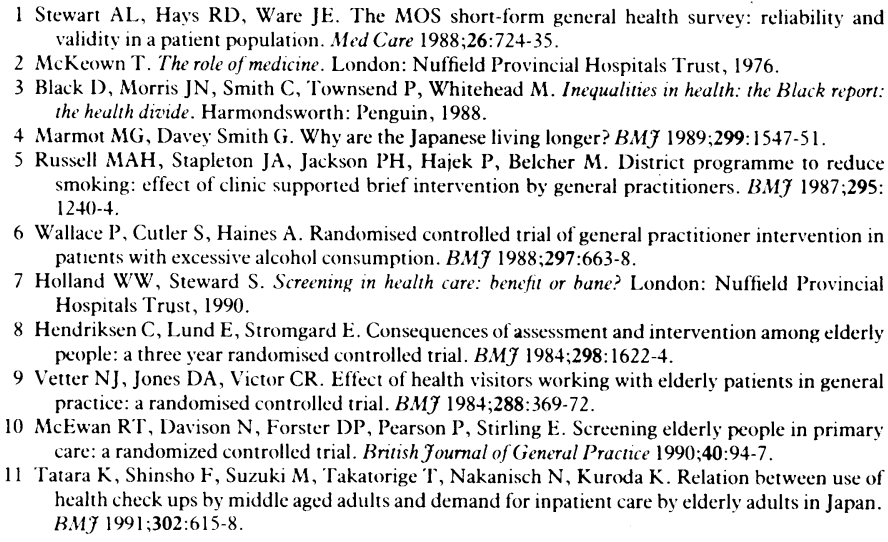

Stewart AL, Hays RD, Ware JE. The MOS short-form general health survey: reliability and validity in a patient population. Med Care 1988;26:724-35.

McKeown T. The role of medicine. London: Nuffield Provincial Hospitals Trust, 1976. 3 Black D, Morris JN, Smith C., Townsend P, Whitehead M. Inequalities in health: the Black report:

Marmot MG, Davey Smith G. Why are the Japanese living longer? BMf 1989;299:1547-51.

Russell MAH, Stapleton JA, Jackson PH, Hajek P, Belcher M. District programme to reduce smoking: effect of clinic supported brief intervention by general practitioners. BMF 1987;295: 1240-4.

6 Wallace P, Cutler S, Haines A. Randomised controlled trial of general practitioner intervention in patients with excessive alcohol consumption. BMF 1988;297:663-8.

Holland WW, Steward S. Screening in health care: benefit or bane? London: Nuffield Provincial Hospitals Trust, 1990

8 Hendriksen C, Lund E, Stromgard E. Consequences of assessment and intervention among elderly people: a three year randomised controlled trial. BMF 1984;298:1622-4.

9 Vetter NJ, Jones DA, Victor CR. Effect of health visitors working with elderly patients in general practice: a randomised controlled trial. $B M 7$ 1984;288:369-72.

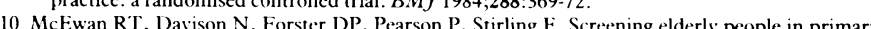
care: a randomized controlled trial. British foumal of General Practice 1990;40:94-7.

11 Tatara K, Shinsho F, Suzuki $M$, Takatorige T, Nakanisch N, Kuroda K. Relation between use of health check ups by middle aged adults and demand for inpatient care by elderly adults in Japan. BMF 1991;302:615-8.

\section{What should be done about asymptomatic hypercholesterolaemia?}

\section{A population based strategy of dietary change has been recommended for Canadians}

Screening hand luggage for explosive devices is widely accepted at airports throughout the world. In contrast, screening for hypercholesterolaemia, which in some people is analogous to carrying around a biological time bomb, is contentious. Several organisations have addressed this issue recently, ${ }^{1-5}$ but confusion still reigns on which policy to pursue. ${ }^{6}$ A report on blood cholesterol testing by the Standing Medical Advisory Committee currently being considered by the Department of Health should eventually dispel this confusion. ${ }^{7}$ In the mean time, an exhaustively thorough appraisal of the whole issue has just appeared from Canada. ${ }^{8}$

The $25-30 \%$ decrease in mortality from coronary heart disease observed in Canada between 1972 and 1982 occurred before screening had become widespread. As most of the coronary heart disease in a population occurs in the many with moderate hypercholesterolaemia rather than the few with severe hypercholesterolaemia, ${ }^{9}$ a population based strategy of dietary change would seem likely to be more effective than a. case finding approach. Although hypercholesterolaemia increases the relative risk of coronary heart disease, especially when accompanied by other risk factors, two thirds of men aged 55 between the highest quintiles of blood pressure and cholesterol remain free from coronary heart disease until the age of 70. Thus measurement of serum total cholesterol concentration is not a highly sensitive predictor of coronary heart disease, the report reasons, nor is prediction improved greatly by assaying high density lipoprotein cholesterol and triglyceride and calculating low density lipoprotein cholesterol concentration because the imprecision of these measurements often results in misclassification of risk.

The approach taken by the United States national cholesterol education programme, with its emphasis on the detection and treatment of people at risk, was rejected by the Toronto working group on the grounds of the massive expansion of laboratory and dietetic facilities that this would entail, the huge increase in time needed to manage hyperlipidaemia by doctors, and the costs of treating perhaps one in four adults with lipid lowering drugs.

Against this background the Toronto working group did not recommend mass screening but strongly advocated a population based strategy of dietary change, with opportunistic screening limited to those at high risk. These are mainly men aged 35-60 with other risk factors; those with known coronary heart disease were regarded separately. In agreement with most other advisory bodies, the Toronto working group accepted that a serum cholesterol concentration of less than $5.2 \mathrm{mmol} / \mathrm{l}$ is desirable whereas a value of more than $7 \cdot 8 \mathrm{mmol} / \mathrm{l}$ requires therapeutic intervention.

Not unexpectedly for epidemiologists, the Toronto working group focused its attention on the population rather than on people, whereas clinicians tend to take the opposite view. Thus in another recent review of screening, this time from the United States, three clinicians assessed the same evidence and reached similar conclusions but with one major difference: they advocated that all men have their serum cholesterol concentration measured at least once in early adult life, ${ }^{10}$ as does the British Hyperlipidaemia Association. ${ }^{1}$ This approach would ensure that those with a serum cholesterol concentration of more than $7 \cdot 8 \mathrm{mmol} / \mathrm{l}$ due to genetic factors would be identified and treated as necessary. Changing the population's diet would be ineffective in such people, and they would often be missed if only those with other risk factors were screened. For example, a British survey suggests that screening everyone with a family history of coronary heart disease before 50 or who has a corneal arcus, a xanthelasma, or xanthomata would identify at most only $30 \%$ of individuals with a serum cholesterol concentration of more than $8 \mathrm{mmol} / \mathrm{l}$."

Would measuring the "newer" risk factors, such as apolipoprotein B and lipoprotein (a) improve the detection of people at high risk of coronary heart disease? A good case can be 